\title{
3 quadros revisitados
}

Não vejo nessa cidade

paletas combinadas

às cores noturnas

das luzes e salas pianos

bandejas de prata,

mas como antes

me impressiona caminhar

pela pequena cruzada,

com seus homens

musculosos levantando névoas

de carne assada - as ruas,

mesmo nos filmes e fotos,

são às vezes o último recurso

para confirmarmos:

este aqui não sou eu.

Mas é ainda aqui:

bicicletas desabando

do alto dos andares, geometria descascada

de isopor, o veneno, o veneno

o que vejo ao passar

ou quando olho as imagens

que fiz há dez anos,

o veneno alegre, excitado

daqueles carros velhos,

abandonados no passeio,

homens vigiando a polícia 


\author{
enquanto assam carne, \\ meninas jogo infância \\ e os donos das varandas altas, \\ que curiosamente \\ pensam que dali vêem melhor \\ que embaixo.
}

2

\author{
E se olhar mais uma vez \\ as luzes da sala \\ estão apagadas \\ as imagens que fiz \\ estão dentro de mim \\ mas se tentar \\ se procurar o que existe \\ por trás de todas as distrações, \\ as imagens, veja, muitas \\ delas não mostram o passado \\ são como um interlúdio \\ do toque, o que há nelas \\ quer viver nos dedos.
}

se pudesse escolher apenas uma foto, com qual ficaria?

Vertov. Uma criança olha (está impressa no negativo) fixamente em uma direção mas não posso ver o que está olhando. Sua expressão me lembra a de outra criança que me disse uma vez 
que gostava dos dias de chuva

porque a rua em que morava

alagava

e sua mãe

podia faltar ao trabalho

e não ser demitida.

E se houvesse mais uma? Ou fosse possivel

reinaugurar o mundo de imagens?

Vozes do Haiti. Só vemos

alguns pares de pés

numa praia, eles dançam.

De algum lugar, ouve-se o som

de uma voz, ela diz:

устал

fatigué

Foi o mundo ou fomos nós

que nascemos cansados?

NOTA

* Frederico Klumb nasceu no Rio de Janeiro, em 1990, é escritor, poeta e cineasta. Cursou Cinema na PUCRio. É autor de Arena (megamíni, 2017), máquinas mancas da manhã (Edições Garupa, 2018) e coautor de Almanaque Rebolado (Azougue; Cozinha Experimental; Edições Garupa, 2016), escrito a 20 mãos. Participou de antologias como Golpe: manifesto (Nosotros Editorial) e da exposição Rejuvenesça: Poesia Expandida Hoje. Publicou poemas e contos em revistas nacionais e estrangeiras, como Modo de Usar \& Co, Escamandro, Garupa, Dusie e Continente, além do curta-metragem Agharta (2017) exibido em festivais como o Festival Internacional de Curta-metragens de Hamburgo. Diversos vídeopoemas do autor podem ser vistos em sua página pessoal no vimeo: https://vimeo.com/user43080611. 